amount in the wholesome waters of Class I., but almost universally present, and often in large quantity, in the pernicious water of Class II. They are very variable as to presence and amount in the doubtful waters of Class III. This result is worthy of special attention in view of the different opinions which have been expressed (by Wanklyn, Angus Smith, Frankland, Griess, Ekin, Haines, \&c.) as to the sanitary conditions of nitrites and nitrates in water.

Among the artificially polluted waters were a number of samples of such general character as to be under the gravest suspicion on sanitary grounds (suspicion corroborated in sundry cases by biological tests), in which, nevertheless, nitrites and nitrates were not found; but these waters had an extraordinarily large amount of organic matter, generally accompanied by very large amounts of ammonia.

Looking at the results for Classes I. and II., and bearing in mind the conclusions reached by Müller, Schloesing, and Muntz, Störer, Warrington, and others, as to the process of nitrification being due to presence of an organised ferment or ferments of bacterial character, "the idea suggests itself whether the noxious character of waters containing largely nitrates and nitritesthemselves presumed to be harmless-and but very little organic matter-which ought to be present, of some sort, to support the 'previous contamination view-may not be in reality due to the presence of a special nitrifying ferment, itself to be classed among the lower organismis capable of propa

Two points are noted as requiring caution in regard to the above conclusions: first, the samples may have undergone some chemical change in the interval from their collection to their reaching the analysts (but such changes could hardly have been great); secondly, it was necessary to take exaggerated instances of mischief; and the organic impurities present in the waters concerned may not be the same as those which would produce slighter, but, in time, serious ill effects. Slighter forms of disease, really attributable to drinking water, may perhaps be numerous, and possibly of various types, but generally the diffi. culty will be too great of securing, in view of the many factors concerned, any satisfactory evidence as to their cause.

In regard to determinations of chlorine, the results are in many cases of water from shallow wells, significant enough of contamination by fluid animal excreta. The amount of chlorine in the case of several wells'near the sea, shows the need of thought as to the natural source of a water in drawing conclusions from the presence of chlorides. Even where chlorine has come in with organic matter, this impropriety in too hastily deciding, as is sometimes done, that a small quantity indicates vegetable, and a large quantity animal contamination is illustrated by several cases.

Prof. Martin and Dr. Hartwell were asked to independently mark waters as "dangerous" and "suspicious" on the basis of the biological observations. The results, as summarised in a table, prove that these methods will not afford the means of deciding between a wholesome and an unwholesome natural water. Several of the waters believed to be fairly wholesome, and certainly in use on a large sca!e, are marked "suspicious," while not one of the waters believed to have proved themselves pernicious when used by man, are set down as "dangerous." In many cases the waters which affected rabbits most, contained very large amounts of organic matter, so large as to probably invalidate comparison with natural waters or with the much more dilute specimens of prepared water. On the other hand, with three strengths of a solution of organic material, it was not the strongest that produced the most marked effects. The pernicious character of waters containing relatively but very little organic matter, seemed to be proved by several cases; probably supporting the idea that it is not mainly the amount of organic matter, bnt the presence and nature of low organisms that render drinking-water unwholesome. Much difficulty in interpretation of the biological results seems to have arisen from too great differences of absolute strength in the solutions of organic matter used.

\section{SCIENCE AT KHARKOFF}

THE Society of Naturalists at the Kharkoff University is one of those which were founded a few years ago for the advancement of the natural sciences generally, and especially

${ }^{1}$ Trudy Obshestva Estestvoispytatelei pri Kharkovskom Universitete (Transactions of the Society of Naturalists at the Kharkoff University) for the study of the natural history of Russia in the provinces that surround University towns, and which have already rendered most valuable services in both these directions. The Kharkoff Society of Naturalists, which numbers I 7 members, has already published fifteen volumes of their Transactions (Tmudy), which contain many valuable papers. Of those in the earlier volumes we will only mention, in geology: The chemical researches of rocks and coal of the Dnieper basin, by A. S. Brio ; geological explorations in the government of Kharkoff and in the Coalmeasures of the Don, by A. W. Guroff; and in the basins of the Dnieper and Kalmius, by M. F. Klemm; the explorations of the Delta of the Dnieper, and microscopical analyses of the Dnieper granites and of the fossil trees of Southern Russia, by M. E. Krend= ovsky; the very interesting researches into the formation and shapes of valleys in Southern Russia ; on the crystalline rocks of the Dnieper ; on black earth, on the Devonian formation of the Sosna and Tim river, and on the structure of the mountains of Taurida, by Prof. S. F. Levakovsky ; and on the hydrography of the Nortbern Donets river, by J. T, Morozoff. The attention of the Kharkoff zoologists was especially attracted during recent years to the obnoxious insects which destroyed the crops, and we fira in the Transactions of the Society several papers devoted to the subject, such as a complete description of the locusts and other insects inhabiting corn-fields, by P. W. Ivanoff; on the paresites of the locust and the cornbeetle, by P. T. Stepanoff; and on obnoxious insects of the province of Kharkoff, by W. A. Yaroshevsky. The same anthor has published also nearly complete lists of the Hemiptera, Heteroptera, Diptera, and Lepidoptera of the province of Kharkoff. Among many other contributions in zoology and physiology we notice physiological researches into the structure of the eyes of birds; on the movements of protoplasm, on the air-sacs of birds, and on the mechanism of their breath. ing; on the movements of Unio, and of Anguis fragilis (all with numerous plates), by R. F. Byeletzky ; on water-acarides, by M. E. Krendovsky; on the Bythotrephes of the Sea of Azov, and on a new Polyphemida, by N. P. Pengo; on Infusoriæ, Turbellarix, and Lepidoptera of the province of Kharkoff, by Madame S. M. Pereyaslavtreff; on the development of Nematodes, and on macrobiotus macronyx, Duj., by the late G. M. Radkevitch; and on the Aranex fauna of the province of Kharkoff, by W. W. Reinhard. There are but few papers on botany in the Transactions. K. S. Gornitsky contributes a "Conspectus plantarum" of the Walki district of the province of Kharkoff; E. M. Delarme has two contributions on the anatomy of Coniferæ and on the Kirkazon plants ; N. F. Kransakoff publishes a list of plants of the neighbourhood of Taganrog, and Novocherkask ; and L. W. Reinhard, on the conjugation of zoospores, and on the Characeæ of Middle and Southern Russia. All these papers are profusely illustrated, and sold each separately at very low prices.

The recent (fifteenth) volume of the Transactions (Trudy), contains the work done by the Society in I88I. M. Stepanoff contributes a paper on the very unsettled question as to the metamorphosis of Bombylides. He has found larvæ of Bombylides in cocoons of Stauronotus vastator, Stev.; they support very well temperatures as low as $-20^{\circ}$ Cels., and can remain at life for more than one year. The opinion of $\mathrm{M}$. Zetterstedt as to the larvæ of Bombylides living also freely, nonparasiticallv, in the soil, seemed to be confirmed by M. Stepanoff, who found them in the autumn and in the spring in the soil, but they might have already abandoned their former dwellings. M. Stepanoff gives also a complete description (with coloured drawings) of the larvæ of Systoechus leucophagus, Mg. -M. Kulchitzky contributes two papers; on the endings and ramifications of the motor nerves of the lower vertebrata (the author doubts that the motor nerves necessarily end in small lamellæ under the sarcolemma, as it was observed by Herr Kiihne); and on the origin of the coloured globules of the blood of Mammalia; these last-the author says-arise, not out of protoplasm, but from globules of lymphoid elements which undergo a whole series of very complicated metamorphoses.M. Yaroshevsky gives a list of : Neuroptera and Hymenontera of the province of Kharkoff. The Neuroptera of the close neigh. bourhoods of the Kharkoff city number no Iess than sixty-one species. The Hymenoptera number 400 species, of which no less than $\mathbf{2 3 5}$ are known in the neighbourbood of the Kharkoff city. The same author, in company with M. Sokoloff, contributes a paper on the state of larvæ of the corn-beetle (Anisoplia) during the winter. The recent ravages of the corneetle in Southern Russia had provoked new researches on this 
subject, and a controversy had arisen among Russian entomolo gists, some of them being of the opinion that the larvæe remain during the winter in the upper frozen sheet of the soil, and are in a state of sleep, while others affirmed that they go deeper into the unfrozen soil, and eat there the roots of plants, but die com. pletely if exposed to temperatures below the freezing point. The researches of M.M. Yaroshevsky and Sok loff proved that these larvæ fell asleep when exposed to temperatures below zero, but immediately returned to life as soon as exposed to a warmer temperature. In the frozen soil, whose temperature was one degree below zero, they found plenty of larvæ of Asilus, Elaterido, Heliothis dipsaceus, and whole nests of ants with their larva. All returned $t$ ) life when warmed. M. Byeletsky contribute; a paper on the respiration of the gigantic Salamander, Cryptobranchus japonicus, Hœv., one metre long, and weighing four kilograms (several individuals of the same species measure, as is known, four feet, and weigh nine kilograms). Siebold had already ob erved the very long pauses between the breathings of this Salamander, sometimes lasting for half an hour. M. Byeletsky found that at a temperature of water about $15^{\circ}$ Celsius, his Salamander remained without breatbing sometimes for an hour and a half. In the air it breathed more often. M. W. Reinhard contributes an elaborate paper on the structure and development of freshwater Bryozoa. After a sketch of our present knowledge of the subject-up to the last works of Messrs. Nitsche, Hatschek, Hyatt, and Allmann -the author describes at length the structure of Crystatella mucedo, giving special attenticn to the development of the statoblasts, and the sexual multiplication of Alcyonella fungosa. The paper is accmmanied by seven weli-engraved plates.

\section{THE HIBERNATION OF ALETIA XYLINA $S A Y, \quad I N$ THE UNITED STATES, A SETTLED FACT}

I HAVE already shown in previous remarks before the Association that there were various theories held by com petent men, both en'omologi ts and planters, as to the hibernation of this Aletia (the common Cotton Worm of the South), some believing that it hibernated in the chrysalis state, some that it survived in the moth state, while still otbers contended that it did not hibernate at all in the United States. I have always contended that the moth survives within the limits of the United States, and in this paper the fact of its hibernation, principally under the shelter of rank wire-grass, is established from observations and experiments made during the past winter and spring. The moth has been taken at Archer, Pla., during every winter month until the early part of March, when it began to disappear, but not until eggs were found deposited. The first brood of worms was found of all sizes during the latter part of the same month on rattoon cotton, while chrysalides and fresh moths were obtained during the early part of April.

The fact thus establi-hed has this important practical bearing

"Whereas upon the theory of animal invasion from some exotic country, there was no incentive to winter or spring work looking to the destruction of the moths, there is now every in centive to such action as will destroy it either by attracting it during mild winter weather by sweets, or by burning the grasse in which it shelters. It should also be a warning to cottongrowers to abandon the slovenly method of cultivation which Jeaves the old cotton-stalks standing either until the next crop is planted, or long after that event; for many planters have the habit of planting the seed in a furrow between the old row of stalks. The most careful recent researches all tend to confirm the belief that Gossypium is the only plant upon which the worm can feed, so that, in the light of the facts presented, there is all the greater incentive to that mode of culture which will prevent the growth of rattoon cotton, since it is very questionable whether the moth would survive long enough to perpetuate itsel upon newly-sown cotton, except for the intervention of rattoon cotton."

\section{UNIVERSITY AND EDUCATIONAL INTELLIGENCE}

CAMBridge. - The following Boards of Electors have been thus constituted :-

Professorship of Anatomy: Professors Flower, P.Z.S., Allen

${ }^{1}$ Abstract of a paper read at the Montreal meeting of the Am. Ass. Adv. Sc., by Dr. C. V. Riley.
Thomson, Paget, Huxley, A. Newton, Liveing, Dr. Michael Foster, and Mr. J. W. Clark.

Downing Professorship of Medicine: Sir G. Burrows, Bart., Drs. Farre, Lauder Brunton, R. Quain, Professors Paget, Liveing, Humphry, and Mr. Main.

Professorship of Pathology : Professors Burdon Sanderson, Latham, Humphry, Paget, Sir James Paget, Drs. Michael Foster, J. F. Payne, and W. H. Gaskell.

Professorship of Political Economy : Messrs. L. H. Courtney, M.P., A. Marshall, H. S. Foxwell, R. H. Inglis Palgrave, H. Sidgwick, V. H. Stanton, H. T. Rohy, and Prof. James Stuart. Dr. Michael Foster is appointed an additional member of the Special Boards for Medicine, and for Biology and Geology.

Candidates for the Plumian Professorship must send in their names to the Vice-Chancellor on January 6 ; the election will take place on January $\mathrm{I} 6$.

A report has been issued recommending various modifications in the Previous and General Examinations; it, however, contains no indication of any approaching relief from examination in Greek, or of the introduction of French or German into the ordinary curriculum, or of any natural science subject. As the syndicate contains several 1 ames of scientific weight, this appears rather surprising.

\section{SCIENTIFIC SERIALS}

Bulletins de la Société d'Anthropologie de Paris, tome v. fasc. iii., I882, contain the concluding part of M. G. D'Hercourt's "Ile de Sardaigne." In this paper the author considers at length the nature and presumed purpose of the masive conical structures known as nur-aghes, of which there are upwards of 3000 on the island of Sardinia, generally on, or near the coast. Since Diodoru: of Sicily, who ascribed their origin to Dedalus, they have been a puzzle to the learned. The author's remarks on the intelligence of the modern Sardi, notwithstanding that craniometrically they rank among the lowest European races, gave occasion to various discussions at subsequent meetings. - A communication from M. Beauregard in regard to a discovery, made la-t January by $M$. Crevaux, of an ancient city of the Incas, at Io kilom. from Salta, in the Argentine Republic, whose geographical position the latter was engaged in determining at the time.- On the various races inhabiting French Cochin China, by M. G. de Clanbry, who confirms the general view of the moral and social degradation of the Annamites. He draws attention to the slight distinctions perceptible between the men and women of these tribes in voice, length of hair, gait, features, \&c., and supplies interesting details in regard to the local flora.-M. Topinard, in presenting to the Society Hölder's craniometer, based on geometric methods, described the craniometric and anthropometric instruments in use from Camper's time to our own.-On the merits of M. Beaumanoir's system of comparing the facial and cranial areas, by $\mathrm{M}$. Corre.-A report by $\mathrm{M}$. Deniker of the result of the official examinations for the Society, of an adult ourang-outang, and a young female chimpanzee, recently brought to Paris. The latter, as in the case observed by Darwin, showed its temper like a petulant child, by pouting, kicking, grinding its teeth, and shedding tears. -A paper by M. Corre, on the craniometric relations of certain anthropomorphous apes.-Report by M. de Mortillet of the labours of the Commission appointed to examine and protect the megalithic monuments of France. By the efforts of the Com. missioners the remains at Carnac have been secured from further demolition, and the Locmariaquer group, including in the socalled "Roi des Menhirs" the largest known monolith, has passed by purchase under the control of the State.-On the abnormal development of the teeth in a child's jaw, belonging to the Stone Age, and found at Erlen, near Colmar, by Dr. Col lignon. The general dental system shows a low racial character, while the large permanent molars had come up before the milk teeth had been shed.-A communication by $M$. Hovelacque, on certain ethnographic survivals in Marne and Berry. In the former province it is deemed specially unlucky to use the horses of a deceased person till after his funeral; in the latter the hives must have a black ribbon attached to them while the family wears mourning, and to avert evil fortune from the house of a departed master, one of his nearest relatives must proclaim to the bees that their former owner is dead.-M. Chervin, on the census of the French people in 1881. The author shows that the augmentation since 1876 has been only 20 per 1000 in France, while in England it was 145, and in Germany as much 